\title{
The flora of Malaysia projects
}

\author{
L.G. Saw ${ }^{1,2} \&$ R.C.K. Chung ${ }^{1}$
}

\begin{abstract}
Malaysia has an estimated 15,000 species of vascular plants. Located in the Malesian region, its affinity is Sundaic, having common elements with Sumatra, Java and Palawan. The two halves of Malaysia, Peninsular Malaysia extending from mainland Asia and East Malaysian states of Sabah and Sarawak on the island of Borneo have their own distinct floristic components. Peninsular Malaysia has about 8,200 species of vascular plants and Sabah and Sarawak have an estimated 12,000 species. The flora of Sabah and Sarawak is generally richer than that of Peninsular Malaysia. Due to historical reasons, the flora of Malaysia project is planned in a phased approach. The Tree Flora of Sabah and Sarawak project, initiated in 1991, represents the first systematic modern attempt to document some of the important plant families of these two states. It would take at least another ten years to complete this project. It is estimated that the Flora of Peninsular Malaysia project, initiated in 2005, will take at least 20 years to complete. To achieve these ambitions, there must be continual support in skilled manpower and fund allocations.
\end{abstract}

Key words: Flora, Malaysia, botanical revisions.

\begin{abstract}
Resumo
A Malásia tem um número estimado de 15.000 espécies de plantas vasculares. Localizada na região da Malesia, possui afinidade com a região conhecida como Sundaica, dividindo elementos em comum com a Sumatra, Java e Palawan. A Malásia é constituída por duas partes, sendo que a Malásia peninsular se estende a partir da Ásia continental, enquanto os estados malaios orientais de Sabah e Sarawak, localizados na ilha de Bornéu, têm componentes florísticos particulares e distintos. A Malásia peninsular tem cerca de 8.200 espécies de plantas vasculares e Sabah e Sarawak têm um número estimado de 12.000 espécies. A flora de Sabah e Sarawak é geralmente mais rica do que a península da Malásia. Devido a razões históricas, o projeto flora da Malásia preve uma abordagem em fases distintas. O Projeto Flora Arbórea de Sabah e Sarawak, iniciado em 1991, representa a primeira tentativa moderna e sistemática para documentar algumas das famílias de plantas importantes destes dois estados. Estima-se que sejam necessários de pelo menos mais 10 anos para concluir este projeto. Enquanto isso o Projeto Flora da Maláisa peninsular, iniciado em 2005, vai demorar pelo menos 20 anos para ser concluído. Para concretizar estes planos, deve haver apoio contínuo para treinar e manter mão de obra qualificada e obtenção de financiamento.
\end{abstract}

Palavras-chave: Biodiversidade, ficologia, lista de plantas e fungos do Brasil.

\section{Introduction}

Malaysia is located just north of the equator, straddling between $0^{\circ} 51^{\prime} \mathrm{N}$ and $7^{\circ} 25^{\prime} \mathrm{N}$ with a total landmass of 329,847 square kilometres. The country is separated by the South China Sea into two regions of similar size; Peninsular Malaysia connected to mainland Asia on the western half and the states of Sabah and Sarawak on the island of Borneo on the east. It has a warm equatorial climate with little seasonality, hot and humid throughout the year (Fig. 1). The two geographical halves of Malaysia pose interesting challenges towards documenting the Flora of Malaysia. Peninsular Malaysia, part of the Malay Peninsula (here includes Singapore and Peninsular Thailand) contains the floristic elements of the Sunda Self and also of the mainland Asiatic species from seasonal climates (Wong 1998). Borneo, with its greater isolation from Malay Peninsula, has a flora of Sundaic element; however it has local floristic influences. Therefore these two regions result from quite different botanical past histories. A very brief historical perspective is provided here, highlighting

\footnotetext{
${ }^{1}$ Forest Research Institute Malaysia, 52109 Kepong, Selangor, Malaysia.

${ }^{2}$ Author for correspondence: sawlg@frim.gov.my
} 


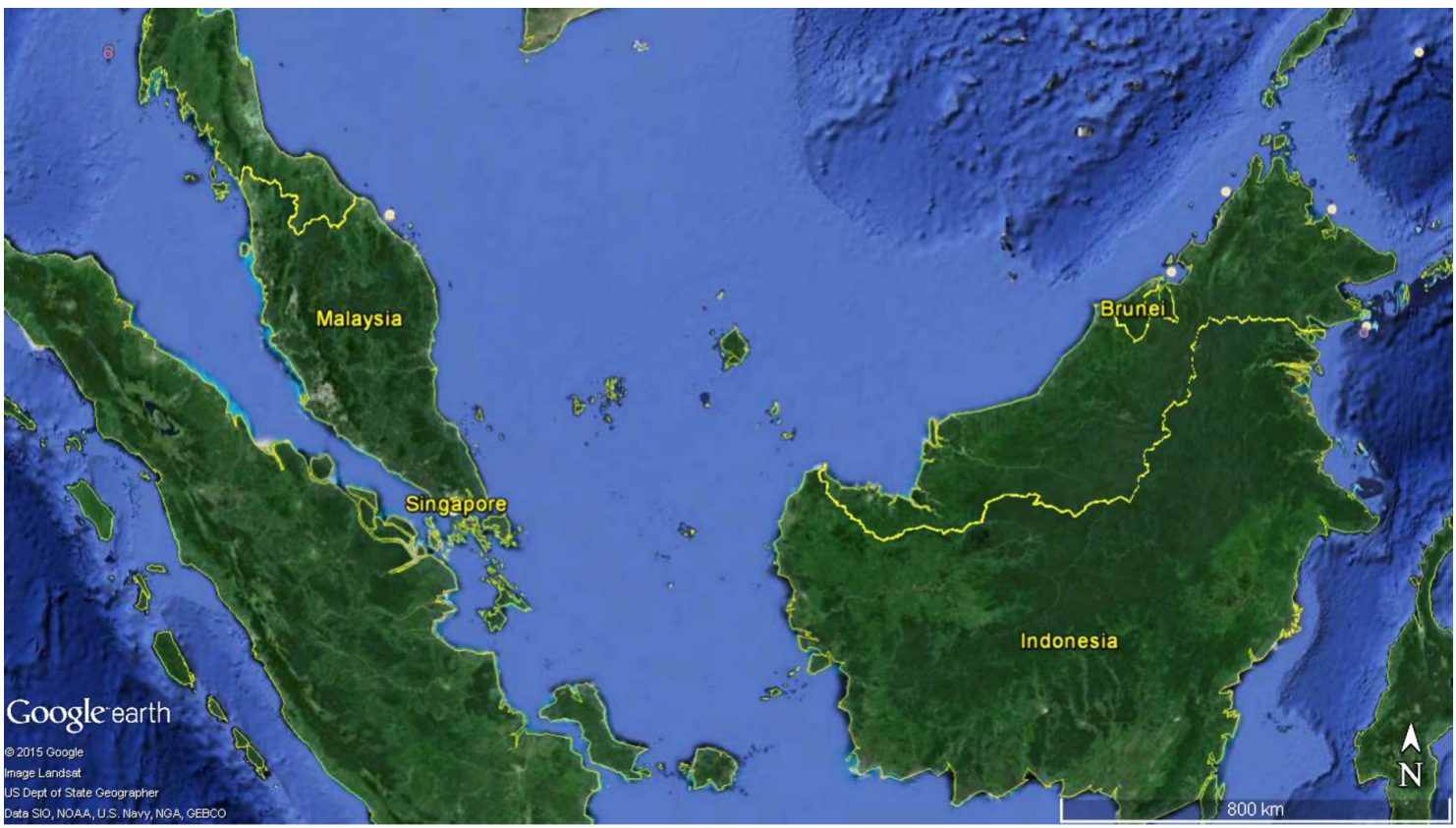

Figure 1 - Map of Malaysia.

only the major works that are significance to the flora of these two regions. A more detailed account of the historical works relating to the flora of both Borneo and Malay Peninsula can be obtained from the introductory volumes of Flora Malesiana (de Wit 1949, van Steenis-Kruseman 1950, van Steenis, 1955). Wong (1987, 1995a) and Soepadmo (1999) also provided reviews with additional updates from de Wit, van Steenis and van Steenis-Kruseman of the botanical collection and documentation of the flora of both Peninsular Malaysia and Borneo. We present here an updated paper in 2005 describing the modern floristic projects we have implemented in Malaysia (see Saw \& Chung 2007).

\section{Methods}

This paper reviewed botanical collections, research, administration and history based on literature, experience for the flora of Malaysia. Acronym of herbaria mentioned in the paper follows Index Herbariorum (Thiers $2015<\mathrm{http}$ ://sciweb. nybg.org/science2/IndexHerbariorum.asp >).

\section{Results and Discussion}

Botanical History of Peninsular Malaysia

Peninsular Malaysia, with a more direct former British Colonial rule had a longer and more sustained period of botanical exploration and enumeration.
Its botanical history dates back to the first British settlement in the early 1800's in Penang, when the island was important for the spice trade. One of the most important collectors during this period include $\mathrm{N}$. Wallich whose collection, organized in a catalogue (Wallich's catalogue), included contributions from G. Porter, W. Jack and G. Finlayson. Numbering about 8,000 species, Wallich's catalogue became the basis of many plant names for Penang and Singapore in Malaya (British colonial boundaries of present day Peninsular Malaysia and Singapore), and India (van Steenis-Kruseman 1950; or see $<$ http:// www.biodiversitylibrary.org/bibliography/40744\#/ summary>). W. Griffith, Wallich's predecessor, collected large numbers of specimens particularly from Malacca and also form the basis of botanical work in Malaya. Many collectors followed included L. Wray Jr., Father Scortechini, H. Kunstler (often labelled as King's Collector), A.C. Maingay, C. Curtis, C.B. Kloss, R. Derry, T. Oxley, J.S. Goodenough, I.H. Burkill, Mohamad Haniff, N. Cantley, F.W. Foxworthy, etc.). A full list of these collectors has been presented by Burkill (1927) with some details of their background while their collection itineraries can be obtained from van Steenis-Kruseman (1950).

H.N. Ridley's arrival to Malaya is a very significant moment for Malayan botany. Between 1888 and 1900, he was appointed as Director of 
Gardens and Forests, Straits Settlements and in 1901-1912, Director of the Gardens, Singapore. Ridley was a man of great ability who contributed most significantly towards the botany of Peninsular Malaysia. In his career, he described over 4,200 plant species. He amassed a huge collection amounting to about 50,000 numbers, of which the main set is at Kew with duplicates in Singapore and other herbaria (van Steenis-Kruseman 1950). No other collector has amassed collections at that rate for for Malaya ever since. Subsequent directors and curators of the herbarium at Singapore Botanic Gardens continued to build upon the foundation set up by Ridley. Of particular importance were the contributions from I.H. Burkill, M.R Henderson, E.H.J. Corner, R.E. Holttum and C.X. Furtado. All of them contributed in the exploration, carried out collections and publications, giving us a better understanding of the flora of Peninsular Malaysia.

At the turn of the twentieth century, A.M. Burn-Murdoch set up a forest herbarium in Kuala Lumpur, with the aim of producing an account of the commercially important tree species of Malaya (Wong 1987). The specimens were collected as reference specimens and duplicates were submitted to H.N. Ridley for identification. The small herbarium was at the office of the Conservator of Forests, Strait Settlements and Federated Malay States. His successor, G.E.S. Cubitt continued with the collection although at a slower rate. In 1916, the Wray Herbarium of the Agriculture Department was transferred to the Forest Department in Kuala Lumpur (Cubitt 1919). In 1918 Cubitt secured the services of F.W. Foxworthy, as the first Forest Research Officer of the Federated Malay States and Straits Settlements. Under Foxworthy the herbarium grew quickly. By the end of 1920, the herbarium contained over 6000 numbers (Wong 1987). With the decision to form a Forest Research Institute (FRI), an area of about 324 hectares was acquired at Kepong in 1926 and the main office building was constructed in 1929 with the herbarium moving into the east wing of the building. C.F. Symington joined FRI in 1929 and began to assist the running of the herbarium. He contributed a large collection to the Kepong herbarium focusing on the important timber family Dipterocarpaceae for which he was preparing a foresters' manual. By the time second World War broke out in Malaya with J.G. Watson having succeeded Foxworthy, the herbarium had about 43,000 specimens. Unfortunately, during the war many of the specimens were badly damaged when looters plundered the herbarium. With the internment of the British officers, V.L. Bain, a Eurasian being exempted from detention was appointed acting State Forest Officer of Selangor. He was able to reappoint several local staff members at Kepong. Aziz Budin went on to restore the damaged collection and attempted to replace some of the lost specimens either by obtaining duplicates from other herbaria or by making new collections.

After the war, J. Wyatt-Smith took charged of the herbarium and the collection gained momentum. With the formation of the Federation of Malaya in 1957 and subsequently the Federation of Malaysia in 1963, the transition towards Malaysianisation came into being. K.M. Kochummen who joined FRI as Assistant Botanist in 1953 subsequently took charge of the herbarium in 1960. In his career, he collected over 5,000 specimens; Kochummen was an important contributor towards many tree family revisions for both the Tree Flora of Malaya and Tree Flora of Sabah and Sarawak. In 1964, F.S.P. $\mathrm{Ng}$ was recruited as Forest Botanist. By 1965, the collection at FRI numbered over 74,000 specimens (Wong 1987). In 1965, T.C. Whitmore was engaged under the Colombo Plan to lead the Tree Flora of Malaya project (Whitmore 1972). In the years following, Whitmore conducted large collecting expeditions into many parts of Peninsular Malaysia, in particular places not collected previously. The Tree Flora project completed its last volume with the publication of Volume 4 in 1989 ( $\mathrm{Ng} \mathrm{1989).}$ By then the herbarium has accumulated about 130,000 specimens. In 1980, K.M. Wong joined Kochummen managing the FRI collection. L.G. Saw joined the institute in 1982 as Hill Forest Silviculturist, later in 1985 joined the herbarium to study under Kochummen as he was soon to retire. In 1985, the Forest Research Institute Malaysia (FRIM) was formed as a statutory body from FRI and in the years following; the mandate of FRIM was to expand beyond the forestry related flora research it traditionally worked on to now include the study of the entire flora of Malaysia.

In this much summarised collections survey we had to leave out many collectors which would feature in a wider review. Later botanists to join the much expanded role of FRIM included Farah Ghani (deceased), Idris Mohd. Said (since left), L.S.L. Chua, R.C.K. Chung, Y.Y. Sam, E. Soepadmo and Ruth Kiew. Since the initiation of the Tree Flora of 
Sabah and Sarawak and later the Flora of Peninsular Malaysia projects, the herbarium at the Forest Research Institute Malaysia has seen a tremendous increase in its botanical staff and capabilities.

\section{Bibliography of the Flora of Peninsular} Malaysia

In the following account, we have restricted the discussion to the main floristic publications that pertain to the flora of the Malay Peninsula. Other incidental accounts of local checklists and revisions of genera can be obtained from the bibliography found in the general chapter of Flora Malesiana Volume 5 (van Steenis 1955) and Turner (1997). The Flora of British India was the first major account covering all the families of Malay Peninsula. The scope of the volumes was to include plants within the British territories of India, together with those of Kashmir and Western Tibet, and Malaya (Hooker 1872-1897 in 7 volumes) as part of the British colony. Plants from Borneo however, were not included in the revisions. Although the Flora of India included treatment of the Flora of the Malay Peninsula, it became apparent that it was not warranted from a phytogeographic perspective and the manner of treatment produced from limited data available at the time had produced an unsatisfactory revision (de Wit 1949). As a result, King (1889), working from the Calcutta Herbarium, initiated the series Materials for a Flora of the Malayan Peninsula. The revisions, written by various authors, were originally published as separate papers in the Journal of the Asiatic Society of Bengal. King and Gamble subsequently compiled these instalments into 4 volumes. King died after completion of Volume 4 and the work of editorship was passed on to J.S. Gamble who continued the series to instalment 26 which were, together with the last instalment published in $1936(\mathrm{Ng} \&$ Jacobs 1983) compiled into Vol. 5. Nevertheless, these volumes covered only the dicotyledonous families and even so, the Urticales viz. Cannabinaceae, Moraceae, Ulmaceae, Urticaceae and most of the Euphorbiaceae never appeared in print $(\mathrm{Ng} \&$ Jacobs 1983). Ridley (1907) published separately in Singapore, in three parts, the Materials for a Flora of the Malayan Peninsula completing the monocotyledons. These publications were very important ground-breaking works and they become the basis for subsequent work on the Flora of the Malayan Peninsula. Using the "Materials" as foundation for the Flora of the Malay Peninsula, Ridley upon his retirement completed the Flora of Malay Peninsula and published them in 5 volumes between 1922 and 1925 (Ridley 1922-1925) for the angiosperms and a separate final fern instalment in 1926 (Ridley 1926).

Following Ridley's publication of the Flora of Malay Peninsula, botanical work continued in more detail and from different perspectives. Burkill (1935), succeeding Ridley, subsequently produced two volumes of $A$ Dictionary of the Economic Products of the Malay Peninsula. Other important publications from Singapore included Corner's (1940) Wayside Trees of Malaya, Henderson's $(1959,1954)$ Malayan Wild Flowers. By the 1950s, a revised Flora of Malaya was initiated as knowledge of the Malayan flora improved with more explorations and collections. A number of publications followed, mainly Zingiberaceae (Holttum 1950), Marantaceae (Holttum 1951), bamboos (Holttum 1958), orchids (Holttum 1964) and ferns (Holttum 1968). The volume on grasses was published by Gilliland (1971). Following the retirement of Holttum from active research due to his old age, the revised Flora of Malaya was more or less discontinued. Piggott (1988) produced a popular photographic account for ferns. The orchid flora was again subjected to another revision by Seidenfaden \& Wood (1992). Turner (1997) collated a checklist of Peninsular Malaysian flora based on literature. More recently, Clarke (2001) published the Nepenthes of Sumatra and Peninsular Malaysia and Kiew (2005) revised the Begonias of Peninsular Malaysia in richly illustrated volumes.

At the Forest Research Institute, Kepong, interest was towards tree species and identification manuals for foresters for the more important timber tree families and other minor forest products. Burn-Murdoch $(1911,1912)$ initiated the first publications of such foresters' manual with the publication of the Trees and Timbers of the Malay Peninsula. The Malayan Forest Records series was started and Foxworthy published a number of volumes on commercial timbers and minor forest products (Foxworthy 1921, 1922, 1932). In 1934, C.F. Symington was appointed the first Forest Botanist and he envisaged producing a foresters' tree manual comprising all the Malayan timberproducing families. However, it was obvious that much research was still required and that a great deal of instability still existed in the botanical 
nomenclature. He then concentrated on the most important timber family, the Dipterocarpaceae, which he completed in 1940 and was published as the Foresters' Manual of Dipterocarps in 1943 in his absence (Symington 1943). Symington had since left Malaya just before the Japanese occupation of Malaya during the Second World War (Symington 1974).

After the War, John Wyatt-Smith served as Forest Botanist. Wyatt-Smith also saw the importance of Symington's work and the need to document similar information on timber trees of other families. However, it became evident that the botanical knowledge of the many non-Dipterocarp trees was inadequate for a similar treatment. In the interim, Wyatt-Smith (1952) produced a booklet listing the more common timber species found in Malaya. K.M. Kochummen subsequently revised this "Pocket Check List" three times to include new information. The Pocket Check List has now become an important identification reference for students and foresters for the common Peninsular Malaysian timber species. The book also standardized vernacular names for timber species. Wyatt-Smith also produced a series of other more taxonomic publications on some of the important timber families such as Burseraceae (Wyatt-Smith 1953a), Leguminosae (Wyatt-Smith 1953b), Myristicaceae (Wyatt-Smith 1953c), Sapotaceae (Wyatt-Smith 1954a), Lauraceae (Wyatt-Smith 1954b) and Sapindaceae (Wyatt-Smith 1954c), and the genus Calophyllum (Guttiferae, Henderson \& Wyatt-Smith 1956).

The Tree Flora of Malaya project under T.C. Whitmore as editor published two volumes (Whitmore 1972, 1973) followed by another two volumes with $\mathrm{Ng}(1978,1989)$ as editor. The final four volumes covered over 2,800 species of trees found in Malaya. Interests in non-timber but commercially important groups resulted in the production of Dransfield's (1979) A manual of the rattans of the Malay Peninsula and K.M. Wong's (1995b) The bamboos of Peninsular Malaysia.

\section{Botanical History of Sabah and Sarawak (and Borneo) \\ Sabah and Sarawak lacked the collection} intensity of Malaya in the early years. However, recent years saw both herbaria at the Forest Research Centres of Sandakan and Kuching steadily increasing their collections. Wong (1995a) has amply summarised the collection history and bibliography of Bornean flora in the introductory chapters of the Tree Flora of Sabah and Sarawak Volume 1 and we shall not elaborate further here. Suffice to add since that review, the Tree Flora of Sabah and Sarawak has published eight volumes (Soepadmo \& Wong 1995; Soepadmo et al.1996; Soepadmo \& Saw 2000; Soepadmo et al. 2002, 2004, 2007, 2011, 2014). The Plants of Kinabalu project led by Beaman published five volumes (Parris et al. 1992; Wood et al. 1993; Beaman \& Beaman 1998; Beaman et al. 2001; Beaman \& Anderson 2004). Modern identification manuals, amounting to floristic enumerations, of the rattans of Sabah and Sarawak (Dransfield 1984, 1992), and the bamboos of Sabah (Dransfield 1992) have been published. More charismatic groups such as orchids and Nepenthes continue to attract interest with publication of checklist of the Orchids of Borneo (Wood \& Cribb 1994), Slipper Orchids of Borneo (Cribb 1997) and the Orchids of Borneo (Beaman et al. 2001), and Nepenthes of Borneo (Clarke 1997). Richly illustrated Etlingera (Zingiberaceae) of Borneo (Poulsen 2006) and Rhododendron (Ericaceae) of Sabah (Argent et al. 2007) were also recently published.

\section{The Flora of Malaysia - What Do We Know?}

Currently there is no comprehensive and up-to-date checklist for the flora of Malaysia. A number of checklists exist as a result of the different botanical history of the two main regions of Malaysia. For Peninsular Malaysia, the now outdated work of Ridley (1922-1926) provided the first complete enumeration of the vascular plants of the Malay Peninsula; the angiosperms were published in the five volumes between 1922 and 1925. Subsequently, Ridley published a separate checklist of the ferns (Ridley 1926). Turner's (1997) publication of "A Catalogue of the Vascular Plants of Malaya" serves as the most recent checklist for Peninsular Malaysia based on an existing literature survey. In this catalogue Turner enumerated 8,198 species (Tab. 1). Parris \& Latiff (1997) published a further update on the ferns and fern allies with some additions and nomenclatural changes to the group (Tab. 2). In this checklist, ferns and fern allies of Sabah and Sarawak were included to provide the first complete checklist of the group for Malaysia.

For Sabah and Sarawak, no checklist exists but two important compilations were made for 
Table 1 - Summary of the checklist of the flora of Peninsular Malaysia comparing Ridley's (1922-1925, 1926) enumeration and Turner's (1997) catalogue.

\begin{tabular}{llccc}
\hline Enumeration & Groups & Families & Genera & Species \\
\hline \multirow{4}{*}{ Ridley (1922-1925, 1926) } & Ferns & 16 & 86 & 417 \\
& Gymnosperms & 3 & 5 & 23 \\
& Dicots & 132 & 1,048 & 5,009 \\
& Monocots & 31 & 354 & 1,734 \\
\hline & Total & 182 & 1,493 & 7,183 \\
\hline \multirow{3}{*}{ Turner (1997) } & Ferns \& fern allies & 34 & 133 & 632 \\
& Gymnosperms & 4 & 8 & 27 \\
& Dicots & 165 & 1,092 & 5,529 \\
& Monocots & 45 & 418 & 2,010 \\
\hline & Total & 248 & 1,651 & 8,198 \\
\hline
\end{tabular}

Borneo (Merrill 1921; Masamune 1942, 1945). Masamune's compilations provided a more critical checklist and in that enumeration, 8,164 species of Bornean vascular plants were listed (Tab. 3). Other and more current accounts for the flora of Borneo were mostly foresters' manuals and checklists often on selected groups in the region or states of Brunei, Kalimantan, Sabah and Sarawak (e.g. Anderson 1980; Argent et al. 1997; Ashton 1964, 1968, 1988; Browne 1955; Burgess 1966; Cockburn 1976, 1980; Hasan \& Ashton 1964; Keith 1947; Kessler \& Sidiyasa 1994; Newman et al. 1996; Primack 1983; Smythies 1965; Whitmore et al. 1990a, 1990b, 1990c; Wood \& Agama 1956; Wood \& Meijer 1964). The other checklists and revisions have been reviewed in the previous section. The launch of the Tree Flora of Sabah and Sarawak in 1991 was very significant and for the first time, used a modern systematic approach to enumerate the trees species (Soepadmo \& Wong 1995). Apart from these enumerations, the other sources of information on the Flora of Malaysia are from the Flora Malesiana Series I \& II for seed plants and ferns and other scattered publications.

Based upon the information above, the flora of Peninsular Malaysia now stands over 8,300 species with recent updates from Turner (1997) (e.g., Turner 2000; Latiff \& Turner 2001a, 2001b, 2001c, 2001d, 2002a, 2002b, 2003; Kamarudin \& Turner 2004). This is probably an accurate estimate. For Sabah and Sarawak it is more difficult to arrive to an accurate figure with most estimates being for
Borneo as a whole Merrill (1921) estimated about 9,000 species, Masamune $(1942,1945)$ enumerated about 8,200 species and more recently Wong (1995a) estimated a flora of between Merrill's 9,000 and 15,000 species. Kiew (1984) stressed the urgency for projects addressing the yet not studied and little understood Bornean flora. At present the Tree Flora of Sabah and Sarawak is the most important modern taxonomic project for Borneo. Since its inception in 1991, eight volumes have been published and provide an indication of the diversity of the Bornean flora. Table 4 provides a comparison of the tree flora of Sabah and Sarawak with the tree flora of Malaya comparing families and their enumeration.

On average, the tree flora of Sabah and Sarawak contain about $38.5 \%$ more species than the tree flora of Malaya. If this proportion is maintained for the rest of the tree flora, considering that the tree flora of Malaya counts with 2,830 species ( $\mathrm{Ng}$ et al. 1990), it is estimated that the tree flora of Sabah and Sarawak will contain about 4,000 species. Based upon this estimation also, with about 8,300 species of vascular plants in Peninsular Malaysia, it is estimated that the flora of Sabah and Sarawak will contain about 11,500 species. In Table 4, there are 889 species common to both Sabah and Sarawak, and Peninsular Malaysia (i.e., $55.1 \%$ overlap with Peninsular Malaysia). Based upon this overlap and using the estimated ratios, the total tree flora of Malaysia is estimated to be around 5,200 species and the total flora of vascular plants of Malaysia around 15,200 species. 
Table 2 - Ferns and fern allies checklist of Parris \& Latiff (1997).

\begin{tabular}{lc}
\hline Region & Species Total \\
\hline Malay Peninsula & 647 \\
Sabah & 750 \\
Sarawak & 615 \\
\hline Total & $1,165^{*}$ \\
\hline * Species distribution overlap between the regions; as a result the total is smaller.
\end{tabular}

Herbaria, Collections and Specimens Specimens are essential for the documentation of the Flora of Malaysia. Today, the collection at the herbarium of the Forest Research Institute Malaysia (KEP) comprises about 400,000 specimens. The other large herbarium holdings include the Forest Research Centre at Sandakan (SAN) with 300,000 specimens and the Forest Research Centre at Kuching (SAR) with about 300,000 specimens (Tab. 5). Other important Malaysian collections are found at the herbaria at University of Malaya (KLU) and Universiti Kebangsaan Malaysia (UKMB). The herbarium at the Singapore Botanic Gardens (SING) is particularly important for the Peninsular Malaysian flora. Many type specimens for plants described from Peninsular Malaysia are found amongst its 750,000 specimens (Tab. 5). Other important collections for the Malaysian flora include Brunei Forest Department (BRUN), Herbarium Bogoriense (BO), the Forest Herbarium (BKF), Bangkok, Thailand, National Herbarium of Netherlands, Leiden (L), Royal Botanic Gardens, Kew (K), Royal Botanic Garden, Edinburgh (E), UK, Arnold Arboretum (A), Harvard University, USA, and Central National Herbarium (CAL), Calcutta, India. For Sabah and Sarawak, O. Beccari's collection in the Herbarium Beccarianum (FI-B), Florence, Italy is particularly important.

\section{State of Knowledge for a Flora of Malaysia}

Among the key resources for speeding up the documentation of a flora of Malaysia is the availability of recent revisions that provide the foundation for flora writing. The vascular flora of Malaysia will include 250 families in Peninsular Malaysia and 253 families in Sabah and Sarawak. In working towards the flora of Malaysia, we have continued to separate the two regions, simply out of convenience from the historical perspective, but also as there is a general tendency in many revisions to maintain the two regions as separate. We have compiled a review of published revisions against the families such as those included in the Flora Malesiana series, Tree Flora of Malaya, the revised Flora of Malaya, Tree Flora of Sabah and Sarawak, and other journal articles or series. In the analysis, out of the 250 families occurring in Peninsular Malaysia, 207 families (83\%) have revisions. For Sabah and Sarawak, the coverage is much lower with 164 families out of 253 (64\%) having revisions. In recent years, world checklists are being generated and these are being made available on the internet, for example, the checklists available from Royal Botanic Gardens, Kew ( $<$ http://www.kew.org/ $\mathrm{wcb} />$ ). Such checklists provide a useful preliminary starting point for flora accounts, especially for Borneo where existing list by Masamune (1942, 1945) have long become obsolete.

\section{Towards a Flora of Malaysia}

In the last two decades, Malaysia has been very fortunate in terms of the resources available to document its floristic diversity. The Tree Flora of Malaya published its final volume in $1989(\mathrm{Ng}$ 1989), but it was clear that the botanical work of documenting the flora of Malaysia needed to continue. It was an obvious decision to extend the well tested formula of the Tree Flora of Malaya and to extend it to Sabah and Sarawak. L.G. Saw, the first author of this paper, was asked to prepare proposals for funding towards a Tree Flora of Sabah and Sarawak project. The project was launched in 1991 with five years funding from the Malaysian Government, the Overseas Development Administration (ODA) of the United Kingdom and the International Tropical Timber Organisation (ITTO). It was originally estimated that the project would run for ten years, cover about 3,000 species (Soepadmo 1995) and be published in eight volumes. Having already completed eight volumes of the tree flora (Soepadmo \& Saw 2000; Soepadmo \& Wong 1995; Soepadmo et al. 1996, 2002, 2004, 2007, 2011, 2014) and with a current estimate of about 4,000 species of trees, we now estimate the Tree Flora of Sabah and Sarawak will need another ten years to complete the remaining estimated 2,000 species at a revision rate of about 200 species per year using present resources.

In realising the flora of Malaysia, a pragmatic approach is to review our existing commitment towards the Tree Flora of Sabah and Sarawak 
Table 3 - The flora of Borneo based on Masamune's checklist (Masamune 1942).

\begin{tabular}{llccc}
\hline Checklists & Groups & Families & Genera & Species \\
\hline Masamune (1945) & Ferns \& fern allies & & 118 & 963 \\
Masamune (1942) & Gymnosperms & 5 & 7 & 34 \\
& Dicots & 133 & 996 & 4,997 \\
& Monocots & 29 & 307 & 2,170 \\
\hline & Total & 167 & 1,428 & 8,164 \\
\hline
\end{tabular}

Table 4 - Revisions of families of the Tree Flora of Sabah and Sarawak compared to the Tree Flora of Malaya. The figures for Tree Flora of Sabah and Sarawak were extracted from volumes 1-8 including 2 single-species families not found in the Tree Flora of Malaya; the figures for the Tree Flora of Malaya were extracted from volumes 1-4 with updates from Turner (1997).

\begin{tabular}{cccccccc}
\hline \multirow{2}{*}{$\begin{array}{c}\text { TFSS } \\
\text { Volumes }\end{array}$} & \multicolumn{2}{c}{ Tree Flora of Sabah \& Sarawak } & \multicolumn{3}{c}{ Tree Flora of Malaya } & Species common \\
\cline { 2 - 6 } & Families & Genera & Species & Families & Genera & Species & to both regions \\
\hline 1 & 31 & 99 & 312 & 31 & 91 & 227 & 152 \\
2 & 23 & 75 & 247 & 21 & 63 & 186 & 116 \\
3 & 4 & 29 & 358 & 4 & 27 & 246 & 139 \\
4 & 6 & 21 & 292 & 6 & 21 & 202 & 106 \\
5 & 4 & 25 & 361 & 4 & 27 & 225 & 132 \\
6 & 4 & 18 & 189 & 4 & 18 & 117 & 82 \\
7 & 3 & 32 & 311 & 3 & 28 & 275 & 111 \\
8 & 3 & 32 & 165 & 3 & 31 & 135 & 51 \\
\hline Total & 78 & 331 & 2,235 & 76 & 306 & 1613 & 889 \\
\hline
\end{tabular}

Table 5 - Important herbarium holdings for Malaysia and Singapore.

\begin{tabular}{llc}
\hline Country & Herbaria & Specimens \\
\hline Malaysia & Forest Research Institute Malaysia & 400,000 \\
& Forest Research Centre, Sandakan, Sabah & 300,000 \\
& Forest Research Centre, Kuching, Sarawak & 300,000 \\
& University Malaya & 65,000 \\
Singapore & Universiti Kebangsaan Malaysia & 72,000 \\
\hline
\end{tabular}

project and attempt to extend it into a full national flora project. The institutions currently engaged in the Tree Flora of Sabah and Sarawak, i.e. the Forest Research Institute Malaysia, and the Forest Departments of Sabah and Sarawak are keen to complete the Tree Flora project and it is clear from the information above that the Flora of Malaysia is best completed in a phased approach. In this pragmatic approach, the flora of Malaysia can be tackled as two regional projects, revisions for Peninsular Malaysia and revisions for Sabah and Sarawak. This is the way forward towards plans to complete the Flora of Malaysia. In April 2004, the Ministry of Natural Resources and 
Environment was formed. With the creation of the ministry, it became a national priority supported by government to document the biodiversity of the country. The work of documenting the flora of Malaysia quickly became a national need and no more an academic wish-list of botanists in Malaysia. Quickly identified was the need for a checklist of its entire flora as Peninsular Malaysia already has a checklist; the immediate need was for Sabah and Sarawak to have an updated list.

In 2005, an application to fund a Flora of Peninsular Malaysia project was made. It was thought that the time was right for such a project as the Tree Flora of Sabah and Sarawak had already been running well for about 15 years and over that period the flora of Peninsular Malaysia had been relatively neglected. Furthermore, as explained earlier, a phased approach to realise the flora of Malaysia seemed a viable option for Malaysia. Subsequently the Flora of Peninsular Malaysia project received five years of funding at the end of 2005. The project has since published six volumes in two series - Ferns \& Lycophytes (Parris et al. 2010, 2013) and Seed Plants (Kiew et al. 2010, 2011, 2012, 2013). For Sabah and Sarawak, the next phase (after the completion of the Tree Flora of Sabah and Sarawak project) will be to start the Flora of Sabah and Sarawak project so that all vascular plants will have been covered. Funding opportunities will need to be sourced in the future.

\section{Collaborations, Contributors and} Rates of Revision

Flora projects are always collaborative involving both local and foreign experts. The experiences from the Tree Flora of Malaya and Tree Flora of Sabah and Sarawak and the Flora of Peninsular Malaysia projects have shown that contributions from experts are essential for their success. Experts often produce revisions at a much faster pace and can tackle groups that are systematically more difficult. At the same time, Malaysian botanists must be trained to become experts so that they will continue to work within the country. Such strategy must be used for a Flora of Malaysia. Currently, the Tree Flora of Sabah and Sarawak and the Flora of Peninsular Malaysia are using such a strategy. Collaborations are at many different levels. At institutional level our traditional partners include local institutes such as Forest Research Centre, Sandakan, Forest Research Centre, Kuching, University of Malaya, Universiti Kebangsaan Malaysia, Universiti Malaysia Sarawak and Universiti Malaysia Sabah. At regional level we collaborate with many herbaria including Singapore Botanic Gardens, Herbarium Bogoriense and the Royal Forest Herbarium, Bangkok. Internationally collaboration includes, the Royal Botanic Gardens Kew, Royal Botanic Garden Edinburgh, the Natural History Museum, London, the National Herbarium of the Netherlands, Leiden, and the Arnold Arboretum, Harvard University, USA. These collaborating institutes are important as they support our research by providing herbarium specimen loans, sourcing of literature, and a wide range of expert advice and support. At present we have over 25 collaborators actively contributing to revisions of families.

To develop and build local expertise two essential elements must be in place; opportunities to build careers in botanical sciences and availability of training regimes for those interested. The Flora of Peninsular Malaysia project when it was first envisage included these elements. We are also very fortunate that, in the last few years, the Forest Research Institute Malaysia has committed to increase the number of botanists to do floristic work. In the last ten years, FRIM has recruited seven new botanists and taken on seven contract researchers for the two projects. Together with existing staff, FRIM now has 16 botanists working on both projects. Training of these new and aspiring botanists became a very important element of both projects. We are confident that, if the current institutional and financial support is maintained, both the Tree Flora of Sabah and Sarawak and the Flora of Peninsular Malaysia projects will be successful and will produce not just the revisions that contribute towards a Flora of Malaysia but also ensure that Malaysia will maintain a pool of botanists trained in understanding the its National flora.

How many years will it take for the current flora projects to complete? It is very important that in planning the delivery of a Flora of Malaysia, we have a realistic estimate of manpower and financial cost. The Tree Flora of Malaya took 24 years to complete. Kiew (1984) made some projections regarding the rate of revision production by botanists in different types of floras (identification and information floras) in past flora projects. They ranged from 250 species per taxonomist per year to 20-30 per year. Taking the 
example of the late K.M. Kochummen, in his seven years tenure as a full-time experienced botanist, he managed to revise 54 species per year for the Tree Flora of Sabah and Sarawak (Tab. 6).

For the Flora of Peninsular Malaysia, Table 7 provides the different rates of revision against the number of full-time staff working on the flora revisions. The matrix estimates the number of years needed to complete the flora of Peninsular Malaysia with the estimated flora of 8,300 species. Using the example of Kochummen, we estimated that for a budding botanist, it would be very difficult to maintain a revision of over 50 species per year. A more realistic figure of about 40 species may be feasible for a relatively grounded botanist. If our current manpower strength is maintained with about 10 fulltime botanists working for the project, we envisage that it will take just over twenty years to complete the Flora of Peninsular Malaysia. This estimate ignores the contributions from other collaborators.

For the Tree Flora of Sabah and Sarawak we have also worked out the rates using similar formulas (Tab. 8). The project with 5 full-time staff will take over twelve years to complete.

Table 6 - Families revised by K.M. Kochummen (1992 - March 1999) during his tenure with the Tree Flora of Sabah and Sarawak project, his average revision rate was 54 species per year.

\begin{tabular}{lll}
\hline Families & Genera & Species \\
\hline Anacardiaceae & 17 & 92 \\
Burseraceae & 8 & 59 \\
Celestraceae & 10 & 44 \\
Moraceae & 5 & 173 \\
Ochnaceae & 5 & 7 \\
\hline Total & 45 & 375 \\
\hline
\end{tabular}

Table 7 - Rate of revision based on about 8,300 species of vascular for the Flora of Peninsular Malaysia.

\begin{tabular}{llllll}
\hline & \multicolumn{5}{l}{ Number of Full-time Staff } \\
\hline & & 5 & 10 & 15 & 20 \\
\hline & 20 & 83 & 42 & 28 & 21 \\
Revision & 30 & 55 & 28 & 18 & 14 \\
Rates/Staff/ & 40 & 42 & 21 & 14 & 10 \\
Year & 50 & 33 & 17 & 11 & 8.3 \\
& 60 & 28 & 14 & 9.2 & 6.9 \\
\hline
\end{tabular}

In our experience, training young botanists is a challenging task. Over the last twenty three years for both the flora projects we have directly trained twenty three individuals in the science of botanical revisions. We consider out of this number only seven have enough experience to independently revise families. Another four still require guidance in their work. The remaining have since left the project to take up other careers not related to botany.

Finances and Institutional Commitment

One of the constant challenges in any flora project is to ensure long-term commitment and sustainability in funding for the continuity of project. Projects are financed in fixed time-frame (e.g., 5 years for the Flora of Peninsular Malaysia), following which it is often difficult to obtain extensions. The Tree Flora of Sabah and Sarawak project has gone through a number of funding changes over the last 15 years; 1991-2006 - ODA, ITTO, Government of Malaysia (Intensification of Research and Development Priority Areas (IRPA) funding); 2006-present - research development funds from the Ninth and Tenth Malaysian Plans. Similarly, we expect the Flora of Peninsular Malaysia to go through various funding challenges as the project develops.

In the future, we are not certain of how we can continue but it is up to the project to develop different ways to maintain funding continuity. We are now working towards funding for the two flora projects as a consolidated project under the Eleventh Malaysian Plan. Whoever the funding comes from it is important such projects have strong institutional commitment, failing which it would be almost impossible to secure continuity in finances and manpower commitment.

It is essential that funding bodies see quality products arising from the project. There is a need to

Table 8 - Revision rates based on about 2,500 species of tree species for the Tree Flora of Sabah and Sarawak.

\begin{tabular}{llllll}
\hline & \multicolumn{5}{c}{ Number of Full-time Staff } \\
\hline & & 5 & 10 & 15 & 20 \\
\hline Revision & 20 & 25 & 12.5 & 8.3 & 6.3 \\
Rates/ Staff/ & 40 & 16.7 & 8.3 & 5.6 & 4.2 \\
Year & 12.5 & 6.3 & 4.2 & 3.1 \\
& 50 & 10 & 5 & 3.3 & 2.5 \\
& 60 & 8.3 & 4.2 & 2.8 & 2.1 \\
\hline
\end{tabular}


be creative in selling the products from the project, outside the standard flora volumes and more innovative methods must be used to disseminate the results of the projects to a wider audience so that they can be seen as pertinent and relevant to both national and scientific needs.

\section{Conclusion}

The Tree Flora of Sabah and Sarawak has produced eight volumes to date, FRIM is currently making information from the project available on the internet thus disseminating the results of the project to the wider public. The Flora of Peninsular Malaysia is being implemented together with a conservation project of threatened plants of Peninsular Malaysia, thus extending the taxon information with distribution to be used in conservation. Here too, the project has been productive and has now generated six volumes in two series. We are now in the process of including all revisions available on the web. This will be launched in the near future using software BRAHMS (Botanical Research And Herbarium Management System) online software. Such achievements will certainly complement the global effort towards the World Flora Online project.

Based upon the discussion above, the phased approach towards a Flora of Malaysia the following points are reiterated.

- The inventory for a Flora of Malaysia can be done with resources in Malaysia and collaboration with our traditional partners;

- Based on current Tree Flora of Sabah and Sarawak and the Flora of Peninsular Malaysia projects, the Flora of Malaysia to continue with the geographical division of Peninsular Malaysia and Sabah \& Sarawak;

- The project to be phased into the immediate short-term needs (checklists) and revisions of the two geographical floras; and

- Project must be seen as long-term as it requires long-term institutional and financial commitments in order to be brought into completion.

\section{References}

Anderson, J.A.R. 1980. A Checklist of the trees of Sarawak. Forest Department, Sarawak. 364p.

Argent, G.; Campbell, E.J.F. \& Wilkie, P. (eds.). 1997. Manual of the larger and more important nondipterocarp trees of Central Kalimantan, Indonesia. Vol. 1 \& 2. Forest Research Institute, Samarinda. 685p.
Argent, G.; Lamb, A. \& Phillipps, A. 2007. The Rhododendron of Sabah Malaysian Borneo. Natural History Publications (Borneo), Malaysia. Kota Kinabalu, Sabah. 290p.

Ashton, P.S. 1964. Manual of dipterocarp trees of Brunei State. Oxford University Press, London. 242p.

Ashton, P.S. 1968. A manual of the dipterocarp trees of Brunei State and of Sarawak. Borneo Literature Bureau for Sarawak Forest Department, Kuching. 129p.

Ashton, P.S. 1988. Manual of the non-dipterocarp trees of Sarawak. Vol. 2. Dewan Bahasa dan Pustaka for Forest Department Sarawak, Kuching. 490p.

Beaman, J.H. \& Beaman, R.S. 1998. The plants of Mount Kinabalu 3. Gymnosperm and Non-Orchid Monocotyledons. Natural History Publications (Borneo) in association with Royal Botanic Gardens, Kew. 220p.

Beaman, J.H.; Anderson, C. \& Beaman, R.S. 2001. The plants of Mount Kinabalu 4. Dicotyledon Families Acanthaceae to Lythraceae. Natural History Publications (Borneo) in association with Royal Botanic Gardens, Kew. 570p.

Beaman, J.H. \& Anderson, C. 2004. The plants of Mount Kinabalu 5. Dicotyledon Families Magnoliaceae to Winteraceae. Natural History Publications (Borneo) in association with Royal Botanic Gardens, Kew. 609p.

Beaman, J.H. \& Beaman, R.S. 1998. The plants of Mount Kinabalu 3. Gymnosperm and Non-Orchid Monocotyledons. Natural History Publications (Borneo) in association with Royal Botanic Gardens, Kew. 220p.

Beaman, T.E.; Wood, J.J.; Beaman, R.S. \& Beaman, J.H. 2001. Orchids of Borneo. Natural History Publications (Borneo) in association with Royal Botanic Gardens, Kew. 584p.

Browne, F.G. 1955. Forest trees of Sarawak and Brunei. Government Press, Sarawak. 369p.

Burgess, P.F. 1966. Timbers of Sabah. Sabah Forest Records No 6. Forest Department, Sabah. 511p.

Burkill, I.H. 1927. Botanical collectors, collections and collecting places in the Malay Peninsula. The Gardens' Bulletin, Straits Settlements 4: 113-202.

Burkill, I.H. 1935. A dictionary of the economic products of the Malay Peninsula. Vols. 1 \& 2. Governments of the Straits Settlements and Federated Malay States, London. Volume I (A-H) 1-1240p and Volume II (IZ) 1241-2444p.

Burn-Murdoch, A.M. 1911. Trees and timbers of the Malay Peninsula, Part 1. F.M.S. Government Press, Kuala Lumpur. $14 p+13 p l$.

Burn-Murdoch, A.M. 1912. Trees and timbers of the Malay Peninsula, Part 2. F.M.S. Government Press, Kuala Lumpur. $17 \mathrm{p}+6 \mathrm{pl}$.

Clarke, C.C. 1997. Nepenthes of Borneo. Natural History Publications, Kota Kinabalu and Science and Technology Unit, Sabah. 209p. 
Clarke, C.C. 2001. Nepenthes of Sumatra and Peninsular Malaysia. Natural History Publications (Borneo), Malaysia, Kota Kinabalu, Sabah. 329p.

Cockburn, P.F. 1976. Trees of Sabah. Sabah Forest Records No 10. Vol. 1. Forest Department Sabah, Sandakan. 261p.

Cockburn, P.F. 1980. Trees of Sabah. Sabah Forest Records $N^{\circ}$ 10. Vol. 2. Forest Department Sabah, Sandakan. 124p.

Corner, E.J.H. 1940. Wayside Trees of Malaya. 2 vols. United Selangor Press, Kuala Lumpur. VII+772p 269fig+228phot.

Cribb, P.J. 1997. Slipper orchids of Borneo. Natural History Publications, Kota Kinabalu. 118p.

Cubitt, G.E.S. 1919. Report on forest administration for the year 1918. Federated Malay States. F.M.S. Government Press. Kuala Lumpur. 15p.

De Wit, H.C.D. 1949. History of Malaysian phytography. Flora Malesiana I: LXXI-CLXI.

Dransfield, J. 1979. A manual of the rattans of the Malay Peninsula. Malayan Forest Records 29. Forest Department, West Malaysia. 270p.

Dransfield, J. 1984. The rattans of Sabah. Sabah Forest Records 13. Forest Department Sabah, Sandakan. 87p.

Dransfield, J. 1992. The rattans of Sarawak. Royal Botanic Gardens, Kew \& Sarawak Forest Department, Kuching. 233p.

Dransfield, S. 1992. The bamboos of Sabah. Sabah Forest Records No 14. Royal Botanic Gardens, Kew \& Forestry Department Sabah, Sandakan. 94p.

Foxworthy, F.W. 1921. The commercial woods of the Malay Peninsula. Malayan Forest Records 1. Forest Department, Federated Malay States Government, Kuala Lumpur. 195p.

Foxworthy, F.W. 1922. Minor forest products of the Malay Peninsula. Malayan Forest Records 2. Forest Department, Federated Malay States Government, Kuala Lumpur. 217p.

Foxworthy, F.W. 1932. Dipterocarpaceae of the Malay Peninsula. Malayan Forest Records 10. Federated Malay States Government, Singapore. 109p.

Gilliland, H.B. 1971. A revised flora of Malaya. Grasses of Malaya. Vol. 3. Botanic Gardens, Singapore. 319p.

Hasan, P. \& Ashton. P.S. 1964. A checklist of Brunei trees. State Forest Office, Brunei. 132p.

Henderson, M.R. \& Wyatt-Smith, J. 1956. Calophyllum Linn. The Gardens' Bulletin Singapore 15: 375.

Henderson, M.R. 1959. Malayan Wild Flowers, Dicotyledons. Caxton Press Ltd., Kuala Lumpur. 478p.

Henderson, M.R. 1974. Malayan wild flowers, Monocotyledons. Art Printing Works, Kuala Lumpur. $357 \mathrm{p}$.

Holttum, R.E. 1950. The Zingiberaceae of the Malay Peninsula. The Gardens'Bulletin Singapore 13: 1-250.
Holttum, R.E. 1951. The Marantaceae of Malaya. The Gardens> Bulletin, Singapore 13: 254296.

Holttum, R.E. 1958. The bamboos of the Malay Peninsula. The Gardens' Bulletin Singapore 16: 1-135.

Holttum, R.E. 1964. A revised flora of Malaya. Orchids of Malaya. Vol. 1. Botanic Gardens, Singapore. 759p.

Holttum, R.E. 1968. A revised flora of Malaya. Ferns of Malaya. Vol. 2. Botanic Gardens, Singapore. 653p.

Hooker, J.D. 1872-1897. The Flora of British India. Vol. 1-7. L. Reeve \& Co., London. 1: 740, 2: 791, 3: 712, 4: 780, 5: 910, 6: 792, 7: 842.

Kamarudin, M.S. \& Turner, I.M. 2004. Quarterly notes: new taxa and records of Malaysian vascular plants. Folia malaysiana 5: 65-68.

Keith, H.G. 1947. The timbers of North Borneo. North Borneo Forest Records № 3. Published by permission of the Government of the colony of North Borneo. Ye Olde Printerie, Hong Kong. 154p.

Kessler, P.J.A. \& Sidiyasa, K. 1994. Trees of the Balikpapan-Samarinda area, East Kalimantan, Indonesia. Tropenbos Series 7. The Tropenbos Foundation, Wageningen, The Netherlands. 446p.

Kiew, R. 1984. Towards a flora of Borneo. In: Sahid, I. et al. (eds.). Research priorities in malaysian biology. Universiti Kebangsaan Malaysia. Bangi, Selangor. Pp. 73-80

Kiew, R. 2005. Begonias of Peninsular Malaysia. Natural history publications (Borneo), Kota Kinabalu. 308p.

Kiew, R.; Chung, R.C.K.; Saw, L.G.; Soepadmo, E. \& Boyce, P.C. (eds.). 2010. Flora of Peninsular Malaysia. Series II: seed plants. Vol. 1. Malayan Forest Records № 49. Forest Research Institute Malaysia, Kepong, Selangor. 329p.

Kiew, R.; Chung, R.C.K.; Saw, L.G.; Soepadmo, E. \& Boyce P.C. (eds.) (2011). Flora of Peninsular Malaysia. Series II: Seed Plants. Vol. 2. Malayan Forest Records No. 49.235 p.

Kiew, R.; Chung, R.C.K.; Saw, L.G. \& Soepadmo, E. (eds.). 2012. Flora of Peninsular Malaysia. Series II: seed plants. Vol. 3. Malayan Forest Records № 49. Forest Research Institute Malaysia, Kepong, Selangor. 85p.

Kiew, R.; Chung, R.C.K.; Saw, L.G. \& Soepadmo, E. (eds.). 2013. Flora of Peninsular Malaysia. Series II: seed plants. Vol. 4. Malayan Forest Records $N^{\circ} 49$. Forest Research Institute Malaysia, Kepong, Selangor. 405p.

King, G. 1889. Materials for a Flora of the Malayan Peninsula. Journal of the Asiatic Society of Bengal 58: 359-408.

Latiff, A. \& Turner, I.M. 2001a. Quarterly notes: new taxa and records of Malaysian vascular plants. Folia malaysiana 2: 54-56.

Latiff, A. \& Turner, I.M. 2001b. Quarterly notes: new taxa and records of Malaysian vascular plants. Folia malaysiana 2: 127-128. 
Latiff, A. \& Turner, I.M. 2001c. Quarterly notes: new taxa and records of Malaysian vascular plants. Folia malaysiana 2: 203-206.

Latiff, A. \& Turner, I.M. 2001d. Quarterly notes: new taxa and records of Malaysian vascular plants. Folia malaysiana 2: 283-284

Latiff, A. \& Turner, I.M. 2002a. Quarterly notes: new taxa and records of Malaysian vascular plants. Folia malaysiana 3: 67-68.

Latiff, A. \& Turner, I.M. 2002b. Quarterly notes: new taxa and records of Malaysian vascular plants. Folia malaysiana 4: 129-132

Latiff, A. \& Turner, I.M. 2003. Quarterly notes: new taxa and records of Malaysian vascular plants. Folia malaysiana 4: 227-230.

Masamune, G. 1942. Enumeratio Phanerogamarum Bornearum. Taihoku Imperial University, Japan. 739p.

Masamune, G. 1945. Enumeratio Pteridophytarum Bornearum. Imperial University, Japan 124p.

Merrill, E.D. 1921. A bibliographic enumeration of Bornean plants. Journal of Straits Branch Royal Asiatic Society, Special Number. 637p.

Newman, M.F.; Burgess, P.F. \& Whitmore, T.C. 1996. Manuals of dipterocarps for foresters: Borneo Island Light Hardwoods. Royal Botanic Gardens Edinburgh \& CIFOR. Bogor. 275p.

Ng, F.S.P. (ed.). 1978. Tree flora of Malaya. Malayan Forest Records 26. Vol. 3. Forest Department, West Malaysia. 339p.

Ng, F.S.P. \& Jacobs, M. 1983. A guide to King's “Materials for a flora of the Malayan Peninsula". The Gardens' Bulletin Singapore 36: 177-185.

Ng, F.S.P. (ed.). 1989. Tree flora of Malaya. Malayan Forest Records 26. Vol. 4. Forest Department, West Malaysia. 549p.

Ng, F.S.P.; Low, C.M. \& MatAsri, N.S. 1990. Endemic trees of the Malay Peninsula. Research Pamphlet 106. Forest Research Institute Malaysia, Kuala Lumpur. 118p.

Parris, B.S.; Beaman, R.S. \& Beaman, J.H. 1992. The Plants of Mount Kinabalu 2. Ferns. Royal Botanic Gardens, Kew. 165 p.

Parris, B.S. \& Latiff, A. 1997. Towards a Pteridophyte flora of Malaysia: A provisional checklist of taxa. Malayan Nature Journal 50: 235-280.

Parris, B.S.; Kiew, R.; Chung, R.C.K.; Saw, L.G. \& Soepadmo, E. (eds.). 2010. Flora of Peninsular Malaysia. Series I: Ferns and Lycophytes, Vol. 1. Malayan Forest Records No 48. Forest Research Institute Malaysia, Kepong, Selangor. 249p.

Parris, B.S.; Kiew, R.; Chung, R.C.K. \& Saw, L.G. (eds.). 2013. Flora of Peninsular Malaysia Series I: Ferns and Lycophytes, Vol. 2. Malayan Forest Records № 48. Forest Research Institute Malaysia, Kepong, Selangor. 241p.

Piggott, A.G. 1988. Ferns of Malaya in colour. Tropical Press Sdn. Bhd. Kuala Lumpur, Malaysia. 458p.
Poulsen, A.D. 2006. Etlingera of Borneo. Natural History Publications (Borneo) in association with Royal Botanic Garden Edinburgh, Kota Kinabalu. 263p.

Primack, R.B. 1983. Forester's guide to the Moraceae of Sarawak. Forest Department Sarawak, Kuching. 140p.

Ridley, H.N. 1907. Materials for a Flora of the Malayan Peninsula. 3 Parts. Methodist Publishing House, Singapore. Part 1, 233p.; Part 2, 235p.; Part 3, 197p.

Ridley, H.N. 1922-1925. The flora of the Malay Peninsula. Vol. 1-5. L. Reeve \& Co. Ltd, London. 1: 918, 2: 672, 3: 405, 4: 383, 5: 470 .

Ridley, H.N. 1926. The ferns of the Malay Peninsula. Journal of the Malayan Branch, Royal Asiatic Society 4: 1-121.

Saw, L.G. \& Chung, R.C.K. 2007. Towards the flora of Malaysia. In: Chua, L.S.L.; Kirton, L.G. \& Saw, L.G. (eds.). Proceedings of seminar and workshop on the status of biological diversity in Malaysia \& threat assessment of plant species in Malaysia. Forest Research Institute Malaysia, Kepong. Pp. 203-219.

Seidenfaden, G. \& Wood, J.J. 1992. The orchids of Peninsular Malaysia and Singapore. Olsen \& Olsen, Fredensborg. 779p.

Smythies, B.E. 1965. Common Sarawak trees. Borneo Literature Bureau, Sarawak. 153p.

Soepadmo, E. 1995. Background to the Tree Flora of Sabah and Sarawak Project. In: Soepadmo, E. \& Wong, K.M. (eds.). Tree Flora of Sabah and Sarawak. Vol. 1. Forest Research Institute Malaysia, Kuala Lumpur, Sabah Forestry Department, Sandakan \& Sarawak Forestry Department, Kuching. Pp. XIII-XIX.

Soepadmo, E. \& Wong, K.M. (eds.). 1995. Tree flora of Sabah and Sarawak. Vol. 1. Forest Research Institute Malaysia, Kuala Lumpur, Sabah Forestry Department, Sandakan \& Sarawak Forestry Department, Kuching. $513 p$.

Soepadmo, E. 1999. Botanical study of Malaysian medicinal plants-an appraisal. In: Manaf Ali, A. et al. (eds.). Phytochemical and biopharmaceutins from the Malaysian rain forest. FRIM \& PSSM, Kuala Lumpur. Pp. 1-14.

Soepadmo, E.; Wong, K.M. \& Saw, L.G. (eds.). 1996. Tree flora of Sabah and Sarawak. Vol. 2. Forest Research Institute Malaysia, Kuala Lumpur, Sabah Forestry Department, Sandakan \& Sarawak Forestry Department, Kuching. 443p.

Soepadmo, E. \& Saw, L.G. (eds.). 2000. Tree flora of Sabah and Sarawak. Vol. 3. Forest Research Institute Malaysia, Kuala Lumpur, Sabah Forestry Department, Sandakan \& Sarawak Forestry Department, Kuching. $511 \mathrm{p}$.

Soepadmo, E.; Saw, L.G. \& Chung, R.C.K. (eds.). 2002. Tree Flora of Sabah and Sarawak, Vol. 4. Forest Research Institute Malaysia, Kuala Lumpur, Sabah Forestry Department, Sandakan \& Sarawak Forestry Department, Kuching. 388p. 
Soepadmo, E.; Saw, L.G. \& Chung, R.C.K. (eds.). 2004. Tree Flora of Sabah and Sarawak. Vol. 5. Forest Research Institute Malaysia, Kuala Lumpur, Sabah Forestry Department, Sandakan \& Sarawak Forestry Department, Kuching. 528p.

Soepadmo, E.; Saw, L.G. \& Chung, R.C.K. (eds.). 2007. Tree Flora of Sabah and Sarawak. Vol. 6. Forest Research Institute Malaysia, Kepong. 335p.Soepadmo, E.; Saw, L.G.; Chung, R.C.K. \& Kiew, R. (eds.). 2011. Tree Flora of Sabah and Sarawak. Vol. 7. Forest Research Institute Malaysia, Kepong. 450p.

Soepadmo, E.; Saw, L.G.; Chung, R.C.K. \& Kiew, R. (eds.). 2014. Tree Flora of Sabah and Sarawak. Vol. 8. Forest Research Institute Malaysia, Kepong. 248p.

Symington, C.F. 1943. Foresters' manual of Dipterocarps. Malayan Forest Records № 16. Syonan-Hakubutukan, Kuala Lumpur. 244p.

Symington, C.F. 1974 (reprint). Foresters' manual of Dipterocarps. Malayan Forest Records No 16. Penerbit Universiti Malaya, Kuala Lumpur. 244p. + plate 1-144.

Thiers, B. 2015. Index Herbariorum: a global directory of public herbaria and associated staff. New York Botanical Garden's Virtual Herbarium. Available at $<$ http://sweetgum.nybg.org/ih/>. Access on 31 July 2015.

Turner, I.M. 1997 ('1995'). A catalogue of the vascular plants of Malaya. The Gardens' Bulletin Singapore 47: 1-757.

Turner, I.M. 2000. The taxonomy of Malaysian vascular plants: new taxa (1996-2000) and endemic genera. Folia malaysiana 2: 41-82.

Van Steenis, G.G.G.J. 1955. Annotated selected bibliography. Flora Malesiana Series I. Vol. 5. Noordhoff-Kolff N.V., Djakarta. 595p.

Van Steenis-Kruseman, M.J. 1950. Cyclopaedia of collectors. Flora Malesiana Series I. Vol. 1. NoordhoffKolff N.V., Djakarta. 639p.

Whitmore, T.C. (ed.). 1972. Tree flora of Malaya. Malayan Forest Records 26. Vol. 1. Forest Department, West Malaysia. 471p.

Whitmore, T.C. (ed.). 1973. Tree flora of Malaya. Malayan Forest Records 26. Vol. 2. Forest Department, West Malaysia. 444p.

Whitmore, T.C.; Tantra, I.G.M. \& Sutisna, U. 1990a. Tree flora of Indonesia. Check list of Kalimantan. Part I. Forest Research and Development Centre, Bogor. Pp. 1-181.

Whitmore, T.C.; I.G.M. \& Sutisna, U. 1990b. Tree flora of Indonesia. Check list of Kalimantan. Part II. 1. Forest Research and Development Centre, Bogor. Pp. 181-429.

Whitmore, T.C.; I.G.M. \& Sutisna, U. 1990c. Tree flora of Indonesia. Check list of Kalimantan. Part II. 2.
Forest Research and Development Centre, Bogor. Pp. 431-620.

Wong, K.M. 1987. The herbarium and arboretum of the Forest Research Institute of Malaysia at Kepong - a historical perspective. The Gardens' Bulletin Singapore 40: 15-30.

Wong, K.M. 1995a. A brief history of botanical collecting and documentation in Borneo. P. XXI-XLI In: Soepadmo, E. \& Wong, K.M. (eds.). Tree flora of Sabah and Sarawak. Vol. 1. Forest Research Institute Malaysia, Kuala Lumpur, Sabah Forestry Department, Sandakan \& Sarawak Forestry Department, Kuching. $513 p$.

Wong, K.M. 1995b. The Bamboos of Peninsular Malaysia. Malayan Forest Records № 41. Forest Research Institute Malaysia, Kepong. 199p.

Wong, K.M. 1998. Patterns of plant endemism and rarity in Borneo and the Malay Peninsula. In: Peng, C.-I. \& Lowry II, P.P. (eds.). Rare, threatened, and endangered floras of Asia and the Pacific Rim. Academia Sinica Monograph Series № 16: 139-169.

Wood, G.H.S. \& Agama, J. 1956. Check list of forest flora of North Borneo. North Borneo Forest Records No 6 . Sunshine Print, Sandakan. 42p

Wood, G.H.S. \& Meijer, W. 1964. Dipterocarps of Sabah (North Borneo). Sabah Forest Records $N^{\circ}$ 5. Forest Department, Sandakan. 344p.

Wood, J.J.; Beaman, R.S. \& Beaman, J.H. 1993. The plants of Mount Kinabalu 2. Orchids. Royal Botanic Gardens, Kew. 411p.

Wood, J.J. \& Cribb, P.J. 1994. A checklist of orchids of Borneo. Royal Botanic Gardens, Kew. 421p. Wyatt-Smith, J. 1952. Pocket check list of timber trees. Malayan Forest Records No 17. Forest Department, Kuala Lumpur. 367p.

Wyatt-Smith, J. 1953a. Manual of Malayan timber trees. Burseraceae. F.R.I. Research Pamphlet No 1. Forest Research Institute, Kepong. 33p.

Wyatt-Smith, J. 1953b. Manual of Malayan timber trees. Leguminosae. F.R.I. Research Pamphlet No 2. Forest Research Institute, Kepong. 74p.

Wyatt-Smith, J. 1953c. Manual of Malayan timber trees. Myristicaceae. F.R.I. Research Pamphlet No 3. Forest Research Institute, Kepong. 25p.

Wyatt-Smith, J. 1954a. Manual of Malayan timber trees. Sapotaceae. F.R.I. Research Pamphlet No 4. Forest Research Institute, Kepong. 56p.

Wyatt-Smith, J. 1954b. Manual of Malayan timber trees. Lauraceae. F.R.I. Research Pamphlet No. 5. Forest Research Institute, Kepong. 64p.

Wyatt-Smith, J. 1954c. Manual of Malayan timber trees. Sapindaceae. F.R.I. Research Pamphlet No. 6. Forest Research Institute, Kepong. 23p. 